\title{
Modelling of Potential Level of Industrial Enterprises
}

\author{
IRYNA YEPIFANOVA \\ Department of Finances and Innovative \\ Management \\ Vinnytsia National Technical University \\ 95, Khmelnytsky highway \\ UKRAINE
}

\author{
VIACHESLAV DZHEDZHULA \\ Department of Finances and Innovative \\ Management \\ Vinnytsia National Technical University \\ 95, Khmelnytsky highway \\ UKRAINE
}

\begin{abstract}
This paper proposes to assess the potential of industrial enterprises using Harrington's desirability function. The approaches to defining the essence and components of potential have been generalized. It is systematized the indicators, which determine the potential of the industrial enterprise. A scientific and

methodological approach to evaluating the level of potential based on the generalized Harrington's criterion has been proposed, which allows generalizing various criteria and factors that determine the potential of the enterprise, convert them into a dimensionless scale and calculate the criterion of desirability - the level of potential. The gradation of values of the desirability function depending on the values of the function has been proposed. The potential of machine-building enterprises has been assessed according to the proposed method.

The results of the study allow a more comprehensive and thorough assessment of the level of potential of the enterprise and identification of areas for its growth.
\end{abstract}

Key-Words: - potential, economic potential, financial potential, labor potential, innovation potential, energy saving potential

Received: December 28, 2020. Revised: May 2, 2021. Accepted: May 21, 2021. Published: May 25, 2021.

\section{Introduction}

In modern business conditions, any business entity is affected by the external environment, which is changeable and dynamic. Taking into account the current economic crisis, caused, in particular, by Covid-19, insufficient level of funding, it is important to manage effectively the potential of the enterprise, which involves, first, its measurement and identification of areas for improvement. Businesses, despite the level of operating conditions, can have significant differences in performance results, which is associated with the rationality of the formation and efficiency of the management system of the enterprise.

The ability of the enterprise to implement the development strategy is determined by various resources and factors that characterize the personnel, financial, organizational, scientific features of the enterprise. Thus, it is the potential of the enterprise that determines its development. To assess the feasibility of implementing the strategies of industrial enterprises, it is necessary to explore the level of potential and determine the most effective direction of financing the implementation of alternative strategies.

However, issues related to assessing the level of potential of the enterprise need more detailed study. There is no approach in the literature, which can comprehensively and thoroughly assess the level of potential of the enterprise and identify areas for its growth.

\section{Literature Review}

In the literature there are different approaches to assessing the level of potential of the enterprise. According to Khachatryan V.V. [1], the assessment of the potential of an industrial enterprise should be based on a comprehensive approach, which provides for complete coverage of components in terms of availability and composition, movement of the latter in dynamics, structural changes, level of efficiency.

According to Otenko I.P. [2], the assessment of potential should be formed on the dialectical unity of static and dynamic approaches. The static approach 
involves identifying the system-forming elements and connections that make up the potential, identifying external and internal factors. The dynamic approach considers changes in the potential that are associated with the processes of operation and development of the enterprise and its external environment.

Kostenyuk Y. B. diagnoses the potential of the enterprise by the method of comparative complex rating assessment with the help of a system of indicators for the following functional blocks: production potential; financial potential; personnel potential; innovation potential [3]. The author uses the score method used to analyse each of these functional blocks as the basis for calculating the final rating.

In the work [4] attention is paid to the possibilities of blockchain technology to strengthen corporate systems and increase the potential of the enterprise.

In the work [5] a model of static and dynamic assessment of enterprise potential has been proposed.

Selezen O.M. proposes to assess the potential of the enterprise by its financial component, using such indicators as liquidity, solvency, financial stability of the enterprise, the coefficient of commercial reputation of the enterprise [6]. The author proposes to define the commercial reputation of the enterprise as the basis for the selection of nine indicators, each of which is evaluated from 0 to 1 point by experts.

In some works, to assess the level of potential, it is proposed to use a system of balanced scores, in particular, this opinion can be found in Gama N., Silva M.M., Ataíde J. [7].

Mourtzisa D., Bolia N., Dimitrakopoulosa G., Zygomalasa S., Koutoupes A. propose to use Teaching Factory to increase the level of enterprise potential, which provides two-way transfer of knowledge in industrial education [8]. According to the scientists using the paradigm of Teaching Factory participants will gain valuable knowledge and be able to cope with the growing industrial needs of the factories of the future.

In [9] it was developed a methodology for selecting innovative enterprise projects that are optimal for investment. Authors proposed to compare project evaluations in the external and internal environment by using a comparative analysis. In this case, the object of research is a portfolio of innovative projects where an indicator of internal competitiveness is calculated by taxonomic assessment for each project.

In [10] authors used consistent fuzzy preference relation analytic hierarchy process.

Harrington's desirability function, which according to [11] is a quantitative, unambiguous, unique and universal indicator of the quality of the studied object, is characterized by such properties as adequacy, efficiency and statistical sensitivity, which allows its use as an optimization criterion. This approach is used by a number of domestic and foreign researchers [12-14]. but requires a clarification and improvement of a set of influencing factors to assess the level of potential of the enterprise.

The aim of this work is to propose the way of evaluating the level of potential based on the generalized Harrington's criterion, which allows generalizing various criteria and factors that determine the potential of the enterprise, convert them into a dimensionless scale and calculate the criterion of desirability - the level of potential.

The advantage of using the Harrington method is its universality - the method allows considering in the model various factors that affected the potential and determine the required indicator.

\section{METHODOLOGY}

The potential of the enterprise can be defined as a set of available intellectual, technological, financial and economic, research and production resources with their appropriate infrastructure, which can create new knowledge and an effective mechanism for commercialization and promote development.

To determine the level of enterprise potential, we propose to use a universal indicator - Harrington's desirability function, because according to [12]: this function is a quantitative, unambiguous, unique and universal indicator of the quality of the object, characterized by properties such as adequacy, efficiency and statistical sensitivity, which allows you to use it as an optimization criterion. This approach is used by a number of researchers, but it is necessary to clarify and improve the set of influencing factors to assess the level of innovation potential.

The assessment of innovation potential by the proposed method should be carried out by selecting a set of influencing factors and calculating their value for each enterprise to be analyzed.

In the literature there are various components of the potential of the enterprise. Thus, Gonchar O. [15] identifies such components of the potential of the enterprise as market, information, industrial, financial, labor components.

According to Turylo A.A., the potential can be divided into [16]:

1. Production - production capacity of the enterprise.

2. Economic - economic opportunities of the enterprise.

3. Market - market opportunities of the enterprise. 
4. Personnel - personnel capabilities of the enterprise.

5. Marketing - marketing opportunities of the enterprise.

6. Intellectual - intellectual capabilities of the enterprise.

7. Information - innovative capabilities of the enterprise.

8. Innovative - innovative capabilities of the enterprise.

Kosteniuk I.V. [3] identifies such components of potential as production potential, financial potential, personnel potential, innovation potential.

In our opinion, in general, the potential of an industrial enterprise is determined by four main components (Fig. 1): financial potential, personnel potential of the enterprise, innovation potential and energy saving potential of the enterprise.

The financial potential allows you to assess the economic capacity of the enterprise to implement enterprise development strategies. This component of potential includes the ability of the enterprise to form the required amount of financial support. In our work, the most important, in our opinion, factors that allow you to assess the financial condition of the enterprise are selected.

The personnel potential of the enterprise consists of the potential of employees to implement development strategies of the enterprise. First of all, this ability is determined by the level of education and experience of employees.

The innovative potential allows you to determine the availability of scientific basis and highly qualified personnel at the enterprise, the ability of the enterprise to implement innovations.

The potential for energy saving allows you to assess the potential for reducing the cost of energy resources in the production and for household needs of the enterprise. These costs are divided into two main groups: thermal energy (thermal potential) and electric energy (electric potential).

All factors of influence selected for use are unilateral, i.e. the growth of the utility function occurs only when moving in the area of determination of factors is in one direction. The usefulness of the vast majority of factors increases with increasing values of the factors themselves, except for some, for example: with increasing depreciation of tangible or intangible assets, usefulness decreases, with increasing financial risk the usefulness for innovation will also decrease. Therefore, a one-sided utility function is considered.

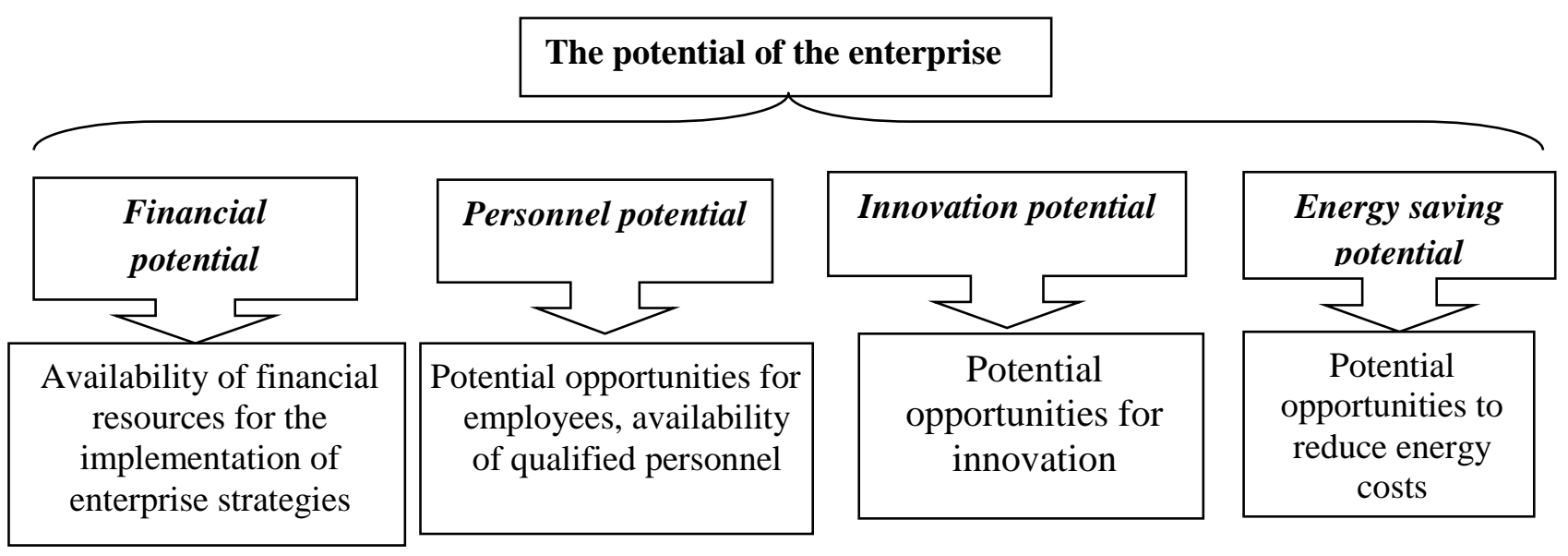

Figure 1: Components of the innovation potential of industrial enterprises

Table 1 summarizes all the factors influencing the development of innovation potential. The main influencing factors that characterize the potential, in our opinion, are divided into four groups according to the type of potential to which they belong.

On the basis of the above components of the potential of the industrial enterprise, a single generalizing criterion is calculated, which includes the value of all factors. To assess the level of potential, we have chosen to use a generalized
Harrington's criterion, which allows you to use different physical values of criteria and factors, translate them into a dimensionless scale and translate to a single dimensionless generalized criterion of desirability D. To translate all these factors into a dimensionless scale it is necessary to create either a translation table or equation and, according to the gradations of Harrington's desirability function, to determine the ranges of the 
values of the input indicators to dimensionless indicators.

Table 1. Factors influencing the enterprise potential

\begin{tabular}{|c|c|c|}
\hline $\begin{array}{c}\text { Potential } \\
\text { component }\end{array}$ & Indicator & $\begin{array}{l}\text { Desig- } \\
\text { nation }\end{array}$ \\
\hline \multirow{4}{*}{$\begin{array}{l}\text { Financial } \\
\text { potential }\end{array}$} & Coefficient of coverage & F1 \\
\hline & Net return on assets & F2 \\
\hline & Financial risk ratio & F3 \\
\hline & $\begin{array}{l}\text { Profitability of operating } \\
\text { activities, \% }\end{array}$ & F4 \\
\hline \multirow{4}{*}{$\begin{array}{l}\text { Personnel } \\
\text { potential }\end{array}$} & $\begin{array}{l}\text { Number of inventions, } \\
\text { patents, innovation } \\
\text { proposals, new products } \\
\text { per employee }\end{array}$ & F5 \\
\hline & $\begin{array}{l}\text { Share of specialists with } \\
\text { higher and secondary } \\
\text { education in the total } \\
\text { number of employees }\end{array}$ & F6 \\
\hline & $\begin{array}{l}\text { Coefficient of physical } \\
\text { performance }\end{array}$ & F7 \\
\hline & $\begin{array}{ll}\text { Coefficient } & \text { of } \\
\text { professional } & \\
\text { development } & \end{array}$ & F8 \\
\hline \multirow{4}{*}{$\begin{array}{l}\text { Innovation } \\
\text { potential }\end{array}$} & $\begin{array}{lrr}\begin{array}{l}\text { Coefficient } \\
\text { development of } \\
\text { products }\end{array} & \text { new } \\
\end{array}$ & F9 \\
\hline & $\begin{array}{l}\text { Coefficient of costs for } \\
\text { the acquisition of new } \\
\text { technologies }\end{array}$ & F10 \\
\hline & $\begin{array}{ll}\text { Coefficient } & \text { of } \\
\text { intellectual property }\end{array}$ & F11 \\
\hline & $\begin{array}{ll}\text { Coefficient } & \text { of } \\
\text { innovation growth }\end{array}$ & F12 \\
\hline \multirow{4}{*}{$\begin{array}{l}\text { Energy } \\
\text { saving } \\
\text { potential }\end{array}$} & $\begin{array}{l}\text { Thermal energy saving } \\
\text { potential }\end{array}$ & F13 \\
\hline & $\begin{array}{l}\text { Electrical energy saving } \\
\text { potential }\end{array}$ & F14 \\
\hline & $\begin{array}{l}\text { Thermal potential of } \\
\text { substitution } \\
\text { alternative } \\
\text { sources }\end{array}$ & F15 \\
\hline & $\begin{array}{lr}\text { Electric potential of } \\
\text { substitution } \\
\text { alternative } \\
\text { sources }\end{array}$ & F16 \\
\hline
\end{tabular}

\section{Source: compiled by the authors}

The gradation of the values of the desirability function $d(y)$ has the following form [9-12]:

- [0... 0.2$]$ - very bad;

- $[0,2 \ldots 0.37]$ - unsatisfactory;
- $[0,37 \ldots 0.63]$ - satisfactory;

- [(0.64 ... 0.8] - good;

- $[0.8 \ldots 0.93]$ - very good;

- $[0.93 \ldots 1]$ - excellent.

Analytically, the desirability function for a group of indicators with a one-sided constraint is given in the form of equation [9-12]:

$$
d(y)=e^{\left(-e^{-y}\right)},
$$

where $\mathrm{d}(\mathrm{y})$ is the desirability function;

$\mathrm{e}$ is the basis of the natural logarithm equal to 2.7182;

$\mathrm{y}$ is the coded argument of the desirability function.

Due to the fact that the improvement of the level of potential of an industrial enterprise changes only with a unilateral change of the coefficients shown in Table 1, the function of desirability with a unilateral restriction is accepted.

The graph of Harrington's desirability function with the zones for estimating the values of the argument in accordance with the theory [9-12] is shown in Fig. 2. In the literature a range of definitions of the argument - coded values $[-6 \ldots 6]$ are usually used, although there are other values of this range in the literature. In our opinion, the use of the range [$2 \ldots 6]$ is the most optimal.

The value of the generalized coefficient of desirability for the above 16 factors will be determined as follows:

$$
D=\sqrt[16]{d_{1} \times d_{2} \times \ldots \times d_{16}}
$$

where $\mathrm{d} 1 \mathrm{-d} 16$ are the values of the desirability functions for the above factors which are determined by Harrington's desirability scale.

Due to the presence of 16 input factors, in accordance with the principles of the theory of desirability function, the exponent of the generalized function uses the root of the 16th degree.

To construct the desirability function, we summarize the above reasonable ranges for determining our factors in the table (Table 2).

Table 2. Ranges of variation of influencing factors 

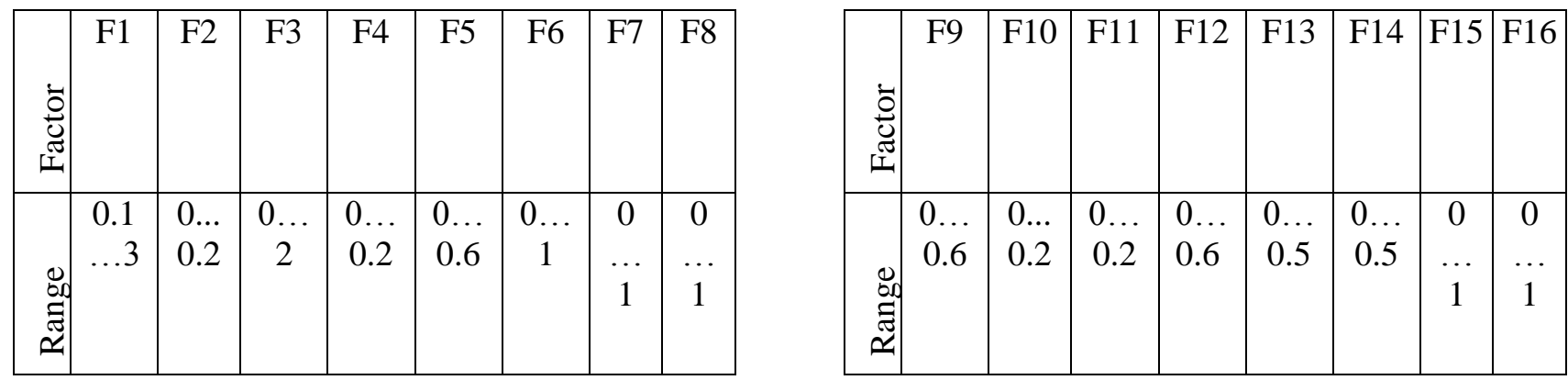

Source: developed by the authors

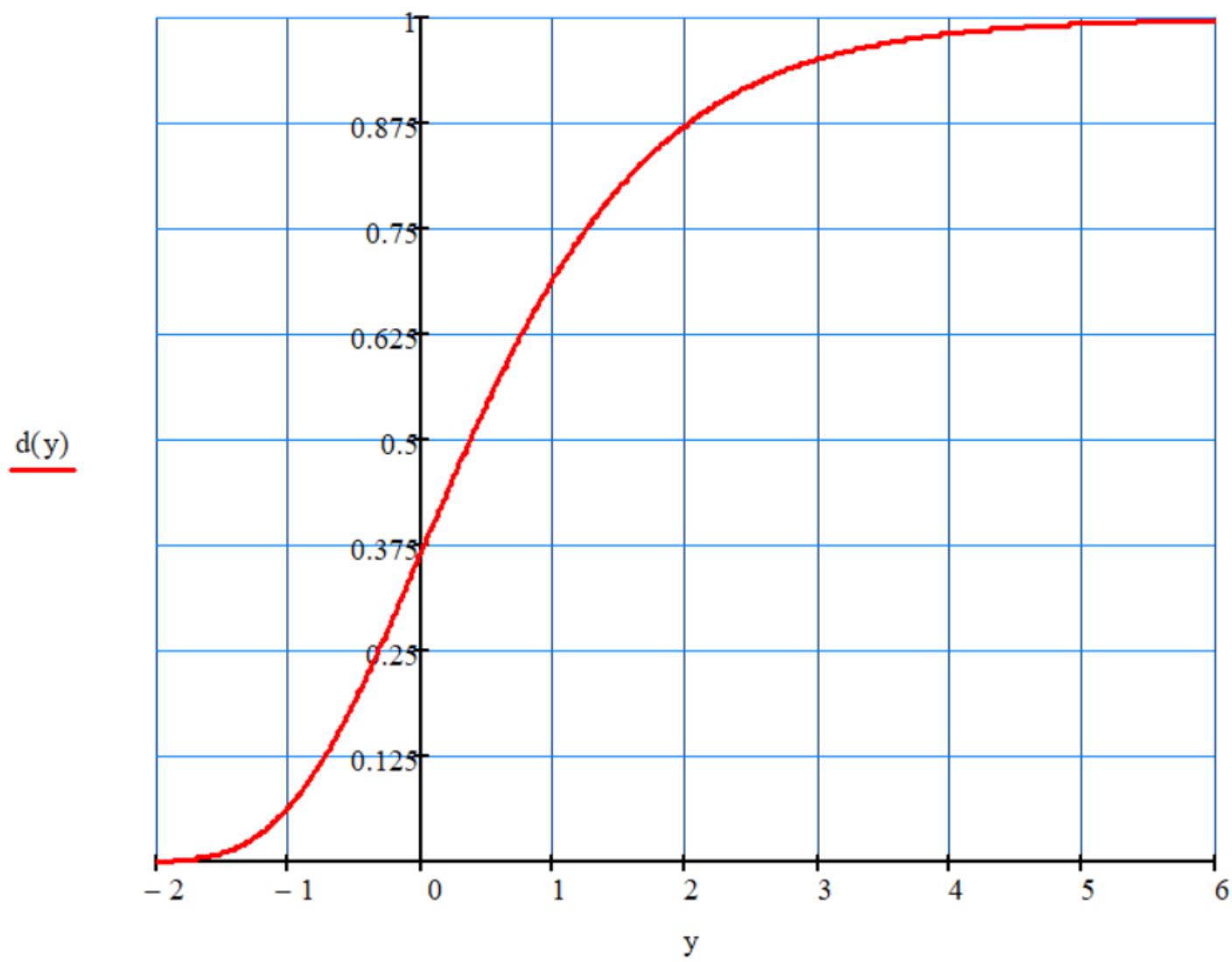

Figure 2: Graph of Harrington's desirability function with a one-sided constraint on the coded scale of the argument

Source: developed by [9-12]

To translate the values of the factors of influence (x) in the coded Harrington's scale (y) we use the following approach. Assume that the relationship between variables is linear and is described by the equation:

$$
y(x)=a_{0}+a_{1} \times x,
$$

where $\mathrm{a}_{0}$ is a free term of the linear equation;

and $\mathrm{a}_{1}$ is the coefficient for the variable $\mathrm{x}$.

There is a problem in determining the values of free terms for each interval of comparison of arguments. The range of definitions for factors F6F8, F15, F16 is the same and has a value of $[0 \ldots 1]$. By graphical comparison it is determined that at the values of the factors $x=0.25$ the value of the coded argument $\mathrm{y}=0$ and the value of the function thus acquires $d=0.37$. When $x=0.5$, the value of the coded argument $y=2$ and the value of the function $d$ $=0.873$. Thus we can make a system of equations:

$$
\left\{\begin{array}{l}
a_{0}+a_{1} \times 0,25=0 \\
a_{0}+a_{1} \times 0,5=2
\end{array}\right\} .
$$




\section{EMPIRICAL RESULTS AND DISCUSSION}

From the system of equations (4) by the method of substitution we determine that $\mathrm{a} 0=-2 ; \mathrm{a} 1=8$. Thus, the equation (3) for the above factors will take the form:

$$
y(x)=-2+8 x .
$$

Then the value of the desirability function for factors F6-F8, F15, F16 will take the form:

$$
d(x)=e^{\left(-e^{-(-2+8 x)}\right)}
$$

The graph of function (6) is shown in Fig. 3. Two scales of input parameters are given along the abscissa axis - coded parameters (y) and values of factors (x).

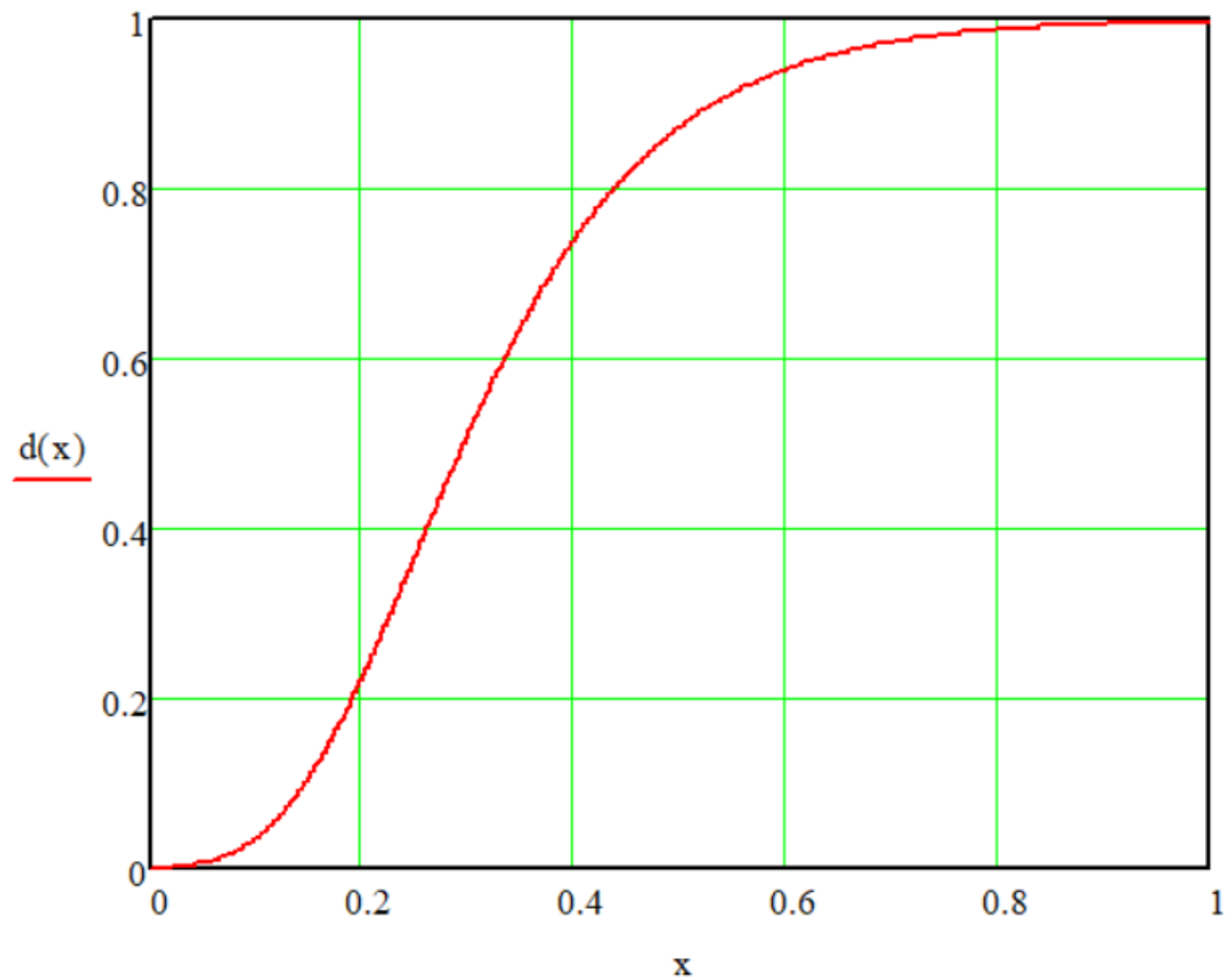

Figure 3: Graph of Harrington's desirability function with a one-sided constraint in the coded scale of argument (y) for the values of the input factors (x) F6-F8, F15, F16

For factors F2, F4, F10, F11 the system of equations will take the form:

$$
\left\{\begin{array}{l}
a_{0}+a_{1} \times 0,05=0 \\
a_{0}+a_{1} \times 0,1=2
\end{array}\right\} .
$$

From the system of equations (7) by the method of substitution we determine that $\mathrm{a} 0=-2$; $\mathrm{a} 1=40$.
Thus, equation (3) for the above factors will take the form:

$$
y(x)=-2+40 x .
$$

Then the value of the desirability function for factors F2, F4, F10, F11 will take the form:

$$
d(x)=e^{\left(-e^{-(-2+40 x)}\right)}
$$


For factors F5, F9, F12 the system of equations will take the form:

$$
\left\{\begin{array}{l}
a_{0}+a_{1} \times 0,15=0 \\
a_{0}+a_{1} \times 0,3=2
\end{array}\right\} .
$$

From the system of equations (10) by the method of substitution we determine that $\mathrm{a} 0=-2 ; \mathrm{a} 1=13.33$. Thus, equation (9) for the above factors will take the form:

$$
y(x)=-2+13,33 x .
$$

Then the value of the desirability function for factors F5, F9, F12 will take the form:

$$
d(x)=e^{\left(-e^{-(-2+13,33 x)}\right)}
$$

For factors F13, F14 the system of equations will look like:

$$
\left\{\begin{array}{l}
a_{0}+a_{1} \times 0,125=0 \\
a_{0}+a_{1} \times 0,25=2
\end{array}\right\} .
$$

From the system of equations (13) by the method of substitution we determine that $\mathrm{a} 0=-2 ; \mathrm{a} 1=16$.

Thus, equation ( 3 ) for the above factors will take the form:

$$
y(x)=-2+16 x .
$$

Then the value of the desirability function for factor F9 will look like:

$$
d(x)=e^{\left(-e^{-(-2+16 x)}\right)}
$$

For factors F3, the system of equations will look like:

$$
\left\{\begin{array}{l}
a_{0}+a_{1} \times 0,5=0 \\
a_{0}+a_{1} \times 1=2
\end{array}\right\} .
$$

Whence by the method of substitution we determine that $\mathrm{a} 0=-2 ; \mathrm{a} 1=4$. Thus, equation (3) for the above factors will take the form:

$$
y(x)=-2+4 x
$$

Then the value of the desirability function for factors F3 will take the form:

$$
d(x)=e^{\left(-e^{-(-2+4 x)}\right)}
$$

For the factor F1, the system of equations will look like:

$$
\left\{\begin{array}{l}
a_{0}+a_{1} \times 0,75=0 \\
a_{0}+a_{1} \times 1,5=2
\end{array}\right\} .
$$

From the system of equations (19) by the method of substitution we determine that $\mathrm{a} 0=-2 ; \mathrm{a} 1=-2.67$. Thus, equation (18) for the above factors will take the form:

$$
y(x)=-2+2,67 x .
$$

Then the value of the desirability function for the factor F1 will look like:

$$
d(x)=e^{\left(-e^{-(2+2,67 x)}\right)}
$$

Thus, analytical equations are constructed to calculate the values of the desirability function for all input factors depending on their values within the range of determination. This approach avoids the direct use of the coded Harrington's scale and the graphical method of determining the values of functions, which is not accurate enough. Using the proposed method, we will assess the level of innovation potential for three industrial machinebuilding enterprises. The calculated values of the initial factors are given in Table 3.

In addition, Table 3 shows the values of the utility function, which are determined according to equations (6), (9), (12), (15), (18), (21). The left part of the table contains the values of the functions obtained analytically, the right - the calculated values of the function.

Intermediate coded values are not given. After determining the utility functions by equation (2), the 
value of the generalized desirability coefficient $\mathrm{D}$ is determined. This property of this function does not allow you to obtain a zero utility result, even for input zero variables.

As can be seen from Table 1, the greatest value of the potential magnitude was acquired by the company with evenly distributed factors approaching their maximum values. Whereas the local peak values of individual factors did not give a significant increase in the generalization function.

Table 3. The results of assessing the innovation potential of industrial enterprises using Harrington's desirability function

\begin{tabular}{|c|c|c|c|c|c|c|}
\hline & \multicolumn{3}{|c|}{ The value of factors ( $x$ ) } & \multicolumn{3}{|c|}{$\begin{array}{l}\text { The value of Harrington's utility } \\
\text { function d (x) }\end{array}$} \\
\hline & 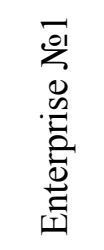 & 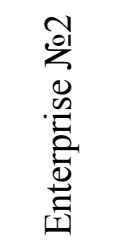 & 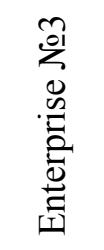 & 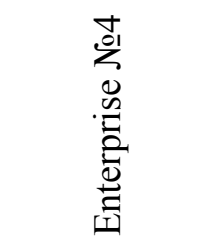 & 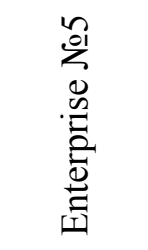 & 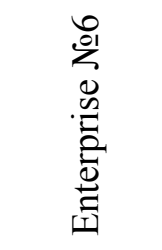 \\
\hline F1 Coefficient of coverage & 0,25 & 1,2 & 2,5 & 0,02258 & 0,74082 & 0,99072 \\
\hline F2 Net return on assets ratio & 0,05 & 0,18 & 0,12 & 0,36788 & 0,99450 & 0,94100 \\
\hline F3 Financial risk ratio & 1,5 & 0,25 & 1,7 & 0,98185 & 0,06599 & 0,99180 \\
\hline $\begin{array}{l}\text { F4 Profitability ratio of operating } \\
\text { activities }\end{array}$ & 0,07 & 0,12 & 0,18 & 0,63806 & 0,94100 & 0,99450 \\
\hline $\begin{array}{l}\text { F5 Number of inventions, patents, } \\
\text { innovation proposals, new } \\
\text { products per employee }\end{array}$ & 0,25 & 0,32 & 0,57 & 0,76811 & 0,90143 & 0,99630 \\
\hline $\begin{array}{l}\text { F6 Share of specialists with higher } \\
\text { and secondary education in the } \\
\text { total number of employees }\end{array}$ & 0,3 & 0,56 & 0,8 & 0,51154 & 0,91967 & 0,98780 \\
\hline $\begin{array}{l}\text { F7 Coefficient of physical } \\
\text { performance }\end{array}$ & 0,8 & 0,7 & 0,93 & 0,98780 & 0,97305 & 0,99567 \\
\hline $\begin{array}{l}\text { F8 Coefficient of professional } \\
\text { development }\end{array}$ & 0,36 & 0,75 & 0,83 & 0,66048 & 0,98185 & 0,99039 \\
\hline $\begin{array}{l}\text { F9 Coefficient of development of } \\
\text { new products }\end{array}$ & 0,32 & 0,15 & 0,55 & 0,90143 & 0,36770 & 0,99517 \\
\hline $\begin{array}{l}\text { F10 Coefficient of costs for the } \\
\text { acquisition of new technologies }\end{array}$ & 0,06 & 0,08 & 0,13 & 0,51154 & 0,73993 & 0,96006 \\
\hline $\begin{array}{l}\text { F11 Coefficient of intellectual } \\
\text { property }\end{array}$ & 0,07 & 0,062 & 0,09 & 0,63806 & 0,53860 & 0,81718 \\
\hline $\begin{array}{l}\text { F } 12 \text { Coefficient of innovation } \\
\text { growth }\end{array}$ & 0,53 & 0,25 & 0,37 & 0,99371 & 0,76811 & 0,94811 \\
\hline \begin{tabular}{lll|} 
F13 Thermal energy & saving \\
potential & & \\
\end{tabular} & 0,32 & 0,41 & 0,46 & 0,95680 & 0,98959 & 0,99531 \\
\hline $\begin{array}{l}\text { F14 Electrical energy saving } \\
\text { potential }\end{array}$ & 0,42 & 0,34 & 0,28 & 0,99112 & 0,96844 & 0,91967 \\
\hline $\begin{array}{l}\text { F15 Thermal potential of } \\
\text { substitution by alternative energy } \\
\text { sources }\end{array}$ & 0,45 & 0,57 & 0,73 & 0,81718 & 0,92561 & 0,97874 \\
\hline $\begin{array}{l}\text { F16 Electrical potential of } \\
\text { substitution by alternative energy } \\
\text { sources }\end{array}$ & 0,23 & 0,59 & 0,75 & 0,30928 & 0,93625 & 0,98185 \\
\hline $\begin{array}{r}\text { Generalized desirab } \\
\qquad D=\sqrt[16]{d_{1} \times d_{2}}\end{array}$ & $\frac{\ldots \times d_{16}}{\ldots+\ldots}$ & & & 0,55998 & 0,70083 & 0,96664 \\
\hline Linguistic ass & ssment & & & satisfactory & good & excellent \\
\hline
\end{tabular}




\section{CONCLUSION}

Thus, the modelling of the potential of industrial enterprises should be carried out on the basis of Harrington's criterion. This criterion allows you to summarize the different physical factors that determine the enterprise potential, translate them into a dimensionless scale and calculate a generalized criterion of desirability. The gradation of values of the desirability function depending on the values of the function has been proposed.

Thus, the authors of the paper have improved the scientific and methodological approach to modeling the potential level, which involves defining the potential as a generalized coefficient of desirability, which depends on the financial, personnel, innovation potential and energy saving potential.

The results of assessing the potential of enterprises using Harrington's desirability function showed that the greatest value of innovation potential value $(0.96664)$ was acquired by an enterprise with evenly distributed factors approaching its maximum values. At the same time, local peak values of individual factors did not give a significant increase in the generalization function.

The results of the study allow a more comprehensive and thorough assessment of the level of enterprise potential of and identification of areas of growth in the formation of development strategy.

The model has been tested on machine-building enterprises, so its use for other industries will require clarification of the set of selected factors.

In further works, this model can be used to ensure sustainable development of the enterprise.

References:

[1] Khachatryan V. V. Entrepreneurial potential of the enterprise in terms of integration changes: formation, management, development: a monograph. Khmelnytsky: Publisher PE Zakolodny MI, 2019.

[2] Otenko I. P. Strategic management of enterprise potential. Kharkiv: KhNEU, 2006

[3] Kosteniuk I. B. Modeling of Enterprise Potential for Development of Management Strategies. Statistics of Ukraine. $2019 . \quad$ 87(4), 21-27. https://doi.org/10.31767/su.4(87)2019.04.03

[4] Haddara M., Norveel J., Langseth M. Enterprise Systems and Blockchain Technology: The Dormant Potentials. Procedia Computer Science. 2021. 181. 562-571. https://doi.org/10.1016/j.procs.2021.01.203.

[5] Gonchar O. Functionally-organizational aspects of potential management of the company based on the synergetics. Scientific bulletin of Polissia. 2015. No. 1 (1). P. $77-$ 84.

[6] Selezen O. M. Estimation of financial potential of the enterprise. Bulletin of Sumy National Agrarian University. Economics and management. 2017. No. 4 (71). Pp. 9699.

[7] Gama N., Silva M. M., Ataíde J. Innovation Scorecard: A Balanced Scorecard for Measuring the Value Added by Innovation. In: Cunha P.F., Maropoulos P.G. (eds) Digital Enterprise Technology. Springer, Boston, MA, 2007.

[8] Mourtzisa D., Bolia N., Dimitrakopoulosa G., Zygomalasa S., Koutoupes A. Enabling Small Medium Enterprises (SMEs) to improve their potential through the Teaching Factory paradigm. Procedia Manufacturing 2018. 23. 183-188.

[9] Romanchik T., Cherkashina M., Shapoval O., Kitchenko O., Heliarovska O. Security Management of Innovation Activity of an Enterprise based on a Multiple-Factor Approach, WSEAS Transactions on Business and Economics, 17, 2020, pp. 664-675

[10] Tzu-Kuang Hsu, Ming-Xiang Chen, MingLang Yeh, Ying-Shen Juang, Construct the Educational Training Model of the Taiwanese Bakery Industry by using Consistent Fuzzy Preference Relation Analytic Hierarchy Process, WSEAS Transactions on Business and Economics, 17, 2020, pp. 1-5.

[11] Harrington E. C. The Desirability Function. Industrial Quality Control. 1965. April. P. 494-498.

[12] Voynarenko M, Dzhedzhula V., Yepifanova I. Modeling of the process of personnel motivation for innovation activity WSEAS Transactions on Business and Economics, 17, 2020, pp. 467-477

[13] Yepifanova, I., Dzhedzhula, V. Methodology of evaluation of innovative potential of enterprises. Agricultural and Resource Economics: International Scientific E-Journal. 2020. No. 6(3), Pp. 171-190. https://doi.org/10.51599/are.2020.06.03.10

[14] Shutyak Y. V. Using the desirability function to assess the economic security of the enterprise. Scientific studies. 2010. vol.7, pp.147-154.

[15] Gonchar O. Management of the potential of an enterprise on the basis of graph-analytical 
models. Scientific bulletin of Polissia. 2017. № 2 (10), V. 2. Pp. 61-65.

[16] Turilo AA The potential of the enterprise: the essence and methodological approaches to the definition. Economic Bulletin. 2014. №3. Pp. 65-71.
Creative Commons Attribution License 4.0 (Attribution 4.0 International, CC BY 4.0)

This article is published under the terms of the Creative Commons Attribution License 4.0

https://creativecommons.org/licenses/by/4.0/deed.en US

Contribution of individual authors to the creation of a scientific article (ghostwriting policy)

Iryna Yepifanova was the author of the idea, structuring the factors

Viacheslav Dzhedzhula has implemented model design, data analysis, implementation of modeling. 